\title{
Free radical scavenging, $a$-glucosidase inhibitory and lipase inhibitory activities of eighteen Sudanese medicinal plants
}

Sara Mustafa Idris Elbashir ${ }^{1}$, Hari Prasad Devkota ${ }^{1,2^{*}}$ (D, Mikiyo Wada ${ }^{3}$, Naoki Kishimoto ${ }^{4}$, Masataka Moriuchi ${ }^{5}$, Tsuyoshi Shuto ${ }^{5}$, Shogo Misumi ${ }^{4}$, Hirofumi Kai ${ }^{5}$ and Takashi Watanabe ${ }^{1,3}$

\begin{abstract}
Background: Lifestyle-related diseases such as diabetes are steadily increasing worldwide. In Sudan, there are a variety of plant species used traditionally for the treatment of diabetes, obesity and other symptoms which need to be validated through scientific studies for their claimed traditional uses. Therefore, in the current study, the free radical scavenging activity, a-glucosidase inhibitory and pancreatic lipase inhibitory activities of 70\% ethanol and water extracts of eighteen Sudanese medicinal plants were investigated using various in vitro assays. Moreover, the cytotoxicity and genotoxicity were assessed for the bioactive plant extracts.
\end{abstract}

Methods: Eighteen plants were selected on the basis of their traditional uses and extracted with $70 \%$ ethanol and water to obtain thirty-six extracts. The obtained extracts were screened using different in vitro bioassays namely, 1,1-diphenyl-2-picrylhydrazyl (DPPH) radical scavenging, a-glucosidase inhibitory and pancreatic lipase inhibitory assays. Furthermore, the active plant extracts were investigated for their cytotoxicity and genotoxicity on HeLa cell line using HCS DNA Damage Assay.

Results: Both 70\% ethanol and water extracts of Acacia nilotica, Ziziphus spina-christi, Abrus precatorius, and Geigeria alata along with the $70 \%$ ethanol extract of Martynia annua showed potent free radical scavenging activity. Regarding the a-glucosidase inhibition assay, both extracts of Acacia nilotica, Ziziphus spina-christi, Geigeria alata, and Cyperus rotundus showed potent activity. In general, 70\% ethanol extracts were more potent compared to water extracts with exception of Cordia sinensis and Cymbopogon proximus, for which water extracts also showed potent enzyme inhibitory activity. Similarly, water extracts of Acacia nilotica and Ziziphus spina-christi showed potent inhibitory activity against pancreatic lipase enzyme. Some of the extracts also showed significant genotoxicity and cytotoxicity at the concentration range used for bioactivities.

Conclusion: The extracts of Acacia nilotica, Ziziphus spina-christi, Geigeria alata, Martynia annua and Abrus precatorius exhibited an appreciable range of activity on antioxidant and enzyme inhibitory assays.

Keywords: Diabetes, Sudan, Medicinal plants, Antioxidant, a-Glucosidase, Pancreatic lipase

\footnotetext{
* Correspondence: devkotah@kumamoto-u.ac.jp

'Department of Medicinal Botany, Graduate School of Pharmaceutical

Sciences, Kumamoto University, 5-1 Oe-honmachi, Chuo-ku, Kumamoto,

Kumamoto 862-0973, Japan

2Program for Leading Graduate Schools, Health Life Science:

Interdisciplinary and Glocal Oriented (HIGO) Program, Kumamoto

University, Kumamoto, Japan

Full list of author information is available at the end of the article
}

(c) The Author(s). 2018 Open Access This article is distributed under the terms of the Creative Commons Attribution 4.0 International License (http://creativecommons.org/licenses/by/4.0/), which permits unrestricted use, distribution, and reproduction in any medium, provided you give appropriate credit to the original author(s) and the source, provide a link to the Creative Commons license, and indicate if changes were made. The Creative Commons Public Domain Dedication waiver (http://creativecommons.org/publicdomain/zero/1.0/) applies to the data made available in this article, unless otherwise stated. 


\section{Background}

Diabetes mellitus (DM) is a serious chronic metabolic disorder, with life-threatening complications. The condition is defined by a state of chronically elevated blood glucose levels (hyperglycemia) with disturbances of carbohydrate, fat and protein metabolism, and mainly caused by deficiency or diminished effectiveness of endogenous insulin [1]. DM is an important cause of mortality and morbidity globally and has considerable health-system costs consequences. According to the World Health Organization (WHO), the total number of people with DM worldwide has substantially increased between 1980 and 2014, rising from 108 million to current numbers of 422 million, which are around four times higher [2]. This rise in the burden of the disease is greatly observed in the middle- and low-income countries compared to high-income countries [3]. In 2017, the International Diabetes Federation (IDF) estimated that $9.6 \%$ adults aged $20-79$ years are living with DM in the Middle East and Northern Africa region, about $49.1 \%$ of them are still undiagnosed and $83.8 \%$ are living in low or middle-income countries, such as Sudan [4].

In Sudan, non-communicable diseases (NCD), including diabetes mellitus have become the principal cause of morbidity and mortality, with an overall prevalence of $10.9 \%$ among adults, according to the IDF $[4,5]$. Furthermore, DM accounts for about $6 \%$ of total deaths from non-communicable diseases in Sudan [6]. In spite of that, diabetes care in Sudan is still very poor to achieve proper glycemic goals and a good quality of life for diabetic patients [7]. According to a recent study conducted in Khartoum state, Sudan, the main factors of the insufficient diabetes services at primary health care centers are the lack of the follow up system for diabetic patients, the insufficient investigations, the lack of diet therapy guidelines and poor patient knowledge and behavior towards the disease management [8]. Moreover, treatment with the current available antidiabetic drugs is still not satisfactory to rectify a normal pattern of glycemic control, and unable to prevent the long-term diabetic complications as well [9]. Therefore, the need for effective, safe and affordable alternative treatment options has become crucial. As an alternative source of medicine, medicinal plants and herbal remedies have always gained a growing public interest across the globe. In Sudan, the use of medicinal plants was always inherent in Sudanese traditional medicine. People in many areas of the country, especially in rural areas, depend mainly on herbal medicine to cure their health problems as they believe in their safety, efficacy, besides to their availability and affordability for a huge sector of the population [10]. One important property of medicinal plants associated with DM treatment is antioxidant activity. There are several scientific reports and clinical evidence that the oxidative stress condition associated with the generation of reactive oxygen species (ROS) increases in both type 1 and type 2 diabetes [11]. It is believed to play an important role in the development of DM vascular complications through endothelial dysfunction and inflammation [12]. In addition, it has been suggested that the cause of the vascular complications in diabetic patients can be due to the insufficient response of the cellular antioxidants against the oxidative stress induced by hyperglycemia [13]. In this context, medicinal plants with potential antioxidant activity may be of great benefit to diminish oxidative stress in diabetic patients and profoundly contribute to reducing the severity and complications of the disease. On the other hand, obesity is a worldwide health problem, which is strongly associated with a number of chronic diseases such as DM [14]. Inhibition of nutrients digestion and absorption is an important target for the treatment of obesity and related diseases like DM. Pancreatic lipase and $\alpha$-glucosidase enzymes inhibitors can lower blood glucose levels by reducing the intestinal absorption of fats and carbohydrates, respectively $[15,16]$.

Fortunately, the flora of Sudan has an immense diversity of indigenous plant species, owing to the fact that they extend over six agro-ecological zones, including desert and semi-desert in the northern part, high and low rainfall savannah to the south, mountain region and flood zone. Several floristic studies revealed that a total of 3137 species of flowering plants representing 170 families exist in Sudan [17]. More than 136 species of them are used commonly as medicinal plants in Khartoum State, from which, 90 plant species indigenous to Sudan [18]. Previous studies have reported a considerable range of biological activities of Sudanese medicinal plants, such as antibacterial $[19,20]$, anthelmintic [21], antiparasitic, antiplasmodial [22], anticancer [23], antidiabetic [24], and many other activities. However, many other Sudanese medicinal plants did not receive any test for their efficacy to validate their claimed traditional uses. In a different study, we screened six medicinal plants from Sudan for their antioxidant and enzyme inhibitory activities using different extraction solvents, and found that the water and aqueous ethanol extracts were suitable solvents for extraction of phenolic compounds [25]. In this context, in the present study, thirty-six extracts derived from 18 plant species belonging to 14 families collected from North Kurdufan and Khartoum states, Sudan (Table 1) were investigated for their potential antioxidant, $\alpha$-glucosidase inhibitory and pancreatic lipase inhibitory activities. The adverse effects and toxicity due to the presence of genotoxic and cytotoxic agents in medicinal plants is important from the point of view of their therapeutic application [26]. Therefore, ten active extracts in antioxidant and enzyme 
Table 1 Scientific name, family, parts used, local name, traditional use and voucher specimen number of species under study

\begin{tabular}{|c|c|c|c|c|c|c|}
\hline No. & $\begin{array}{l}\text { Scientific } \\
\text { name }\end{array}$ & Family & Parts used & $\begin{array}{l}\text { Local name } \\
\text { (Sudanese accent) }\end{array}$ & Traditional use & Voucher specimen no. \\
\hline 1 & Abrus precatorius L. & Fabaceae & Seeds & Habbat Al-Arus & $\begin{array}{l}\text { Used in the treatment of } \\
\text { diabetes mellitus, sterility, } \\
\text { inflammation of the eye, } \\
\text { headache, and as a laxative, } \\
\text { purgative, anti-cough, emetic, } \\
\text { demulcent, and as an agent } \\
\text { in water purification [10]. }\end{array}$ & MAPRI-H.G.117/83 \\
\hline 2 & Acacia nilotica $\mathrm{L}$. & Fabaceae & Pods & Garad, Sunt & $\begin{array}{l}\text { Used in the treatment of } \\
\text { hypertension, diabetes mellitus, } \\
\text { cough and as a gargle } \\
\text { for tonsillitis }[10,48] \text {. }\end{array}$ & MAPRI-H.G.112/83 \\
\hline 3 & $\begin{array}{l}\text { Blepharis linariifolia } \\
\text { Pers. }\end{array}$ & Acanthaceae & Whole plant & $\begin{array}{l}\text { Al-Bighail; Shoak } \\
\text { Al-Dhab, and Siha }\end{array}$ & $\begin{array}{l}\text { Used in the treatment of } \\
\text { urinary disorders (Kidney stones), } \\
\text { as a general tonic, and for } \\
\text { stomach pain [49]. }\end{array}$ & MAPRI-H.M.138/77 \\
\hline 4 & $\begin{array}{l}\text { Boswellia papyrifera } \\
\text { (Del.) Hochst. }\end{array}$ & Burseraceae & Gum & $\begin{array}{l}\text { Tarag tarag, } \\
\text { Shagar El-luban }\end{array}$ & $\begin{array}{l}\text { Used in the treatment of } \\
\text { dysentery, upper respiratory } \\
\text { tract infections, and as an } \\
\text { ingredient of a special } \\
\text { Sudanese incense }[17,50] \text {. }\end{array}$ & MAPRI-H.K.12/96 \\
\hline 5 & $\begin{array}{l}\text { Cephaelis ipecacuanha } \\
\text { (Brot.) A.Rich }\end{array}$ & Rubiaceae & Roots & Irg Al-dahab & $\begin{array}{l}\text { Used in the treatment of } \\
\text { dysentery and as an emetic [51]. }\end{array}$ & MAPRI-H.K.19/53 \\
\hline 6 & Citrullus colocynthis L. & Cucurbitaceae & Seeds & Handal & $\begin{array}{l}\text { Used in the treatment of } \\
\text { diabetes mellitus, gonorrhea, } \\
\text { anti-rheumatic, and against } \\
\text { scabies. It is also used for } \\
\text { making tar (qutran), against } \\
\text { moth, lice, and as anti-scorpion } \\
\text { stings and anti-snake bite }[10,17] \text {. }\end{array}$ & MAPRI-H.O.5/78 \\
\hline 7 & Cordia sinensis Lam. & Boraginaceae & Leaves & Andrab & $\begin{array}{l}\text { Used in the treatment of } \\
\text { diabetes, wound, high fever } \\
\text { and as antitumor }[52,53] .\end{array}$ & MAPRI-H.O.22/78 \\
\hline 8 & $\begin{array}{l}\text { Cymbopogon proximus } \\
\text { (Hochst. ex A. Rich) Stapf. }\end{array}$ & Poaceae & Whole plant & Mahareb & $\begin{array}{l}\text { Used in the treatment of } \\
\text { kidney infections, diabetes, } \\
\text { gout, renal colic, prostatic } \\
\text { enlargement. It also used as } \\
\text { carminative, antispasmodic, and } \\
\text { diuretic }[17,54] \text {. }\end{array}$ & MAPRI-H.12.78 \\
\hline 9 & Cyperus rotundus L. & Cyperaceae & Roots & Si'da & $\begin{array}{l}\text { Used in the treatment of } \\
\text { diabetes, abdominal pain, } \\
\text { diarrhea, as anthelmintic, } \\
\text { astringent, and aromatic [55]. }\end{array}$ & MAPRI-H.ABU.H.16/94 \\
\hline 10 & Geigeria alata DC. & Asteraceae & Aerial parts & El Gadgad & $\begin{array}{l}\text { Used in the treatment of } \\
\text { diabetes mellitus, antihypertensive, } \\
\text { and intestinal complaints, and } \\
\text { cough. It is also used as } \\
\text { antispasmodic }[42,56] \text {. }\end{array}$ & MAPRI-H.G.61/93 \\
\hline 11 & Martynia annua L. & Martyniaceae & Mature Fruit & Gara Gebei & $\begin{array}{l}\text { Used as anthelmintic, antibacterial, } \\
\text { analgesic, anti-venom, antipyretic, } \\
\text { anti-convulsion, antidiabetic and } \\
\text { for wound healing [41]. }\end{array}$ & MAPRI-H.Y.22/14 \\
\hline 12 & $\begin{array}{l}\text { Pennisetum glaucum } \\
\text { (L.) R.Br. }\end{array}$ & Poaceae & Grains & Dukhun & $\begin{array}{l}\text { Used in the treatment of rheumatism } \\
\text { and as a food additive }[10,57] \text {. }\end{array}$ & MAPRI-H.Y.53/010 \\
\hline 13 & Ruta graveolens L. & Rutaceae & Fruit & Sathab & $\begin{array}{l}\text { Used in the treatment of rheumatic } \\
\text { pains [10]. }\end{array}$ & MAPRI-H.Y.7/012 \\
\hline 14 & Solenostemma argel Del. & Apocynaceae & Leaves & Harjal & $\begin{array}{l}\text { Used in the treatment of diabetes } \\
\text { mellitus, epigastric pain, joints affections, } \\
\text { fever, common cold, headache, loin pain, } \\
\text { puerperal fever, nausea, indigestion. Its } \\
\text { beverage is used as laxative, purgative, }\end{array}$ & MAPRI-H.O.12/78 \\
\hline
\end{tabular}


Table 1 Scientific name, family, parts used, local name, traditional use and voucher specimen number of species under study (Continued)

\begin{tabular}{|c|c|c|c|c|c|c|}
\hline$\overline{\text { No. }}$ & $\begin{array}{l}\text { Scientific } \\
\text { name }\end{array}$ & Family & Parts used & $\begin{array}{l}\text { Local name } \\
\text { (Sudanese accent) }\end{array}$ & Traditional use & Voucher specimen no. \\
\hline & & & & & $\begin{array}{l}\text { carminative, and anti-spasmodic } \\
{[10,17,58] \text {. }}\end{array}$ & \\
\hline 15 & Tinospora bakis Miers & Menispermaceae & Roots & Erg El-Haggar & $\begin{array}{l}\text { Used in the treatment of diabetes } \\
\text { mellitus, headache, and abdominal pain. } \\
{[48,59] \text {. }}\end{array}$ & MAPRI-H.M.30/76 \\
\hline 16 & $\begin{array}{l}\text { Trigonella foenum- } \\
\text { graceum } \mathrm{L} \text {. }\end{array}$ & Fabaceae & Seeds & Hilba & $\begin{array}{l}\text { Used in the treatment of diabetes } \\
\text { mellitus, abdominal disorders, dysentery, } \\
\text { and, as anti-spasmodic, antidiarrheal, } \\
\text { anti-amoeba. It is also used as a food } \\
\text { additive and to increase secretion of } \\
\text { milk for lactating mothers }[17,60] \text {. }\end{array}$ & MAPRI-H.Y.6/005 \\
\hline 17 & $\begin{array}{l}\text { Vangueria } \\
\text { madagascariensis } \\
\text { J.F.Gmel. }\end{array}$ & Rubiaceae & Fruit & El-Kirkir & $\begin{array}{l}\text { Used in the treatment of diabetes } \\
\text { mellitus and bacterial infections [61]. }\end{array}$ & MAPRI-H.W.45/95 \\
\hline 18 & Ziziphus spina-christi L. & Rhamnaceae & Roots & Sidir & $\begin{array}{l}\text { Used in the treatment of gonorrhea, } \\
\text { fever, as anti-spasmodic and } \\
\text { anti-purgative }[17,62] .\end{array}$ & MAPRI-H.Y.4/010 \\
\hline
\end{tabular}

inhibitory assays were further investigated for their potential genotoxicity and cytotoxicity on HeLa cells using HCS DNA Damage assay.

\section{Methods}

\section{Plant materials}

Eighteen plant species (Table 1) were collected from North Kurdufan and Khartoum states, Sudan, on March 2016. The target plant parts were separated, identified morphologically, compared with identified herbarium specimens and dried at $60{ }^{\circ} \mathrm{C}$ using an electric oven. All plant samples were authenticated by Mr. Yahya Sulieman Mohamed, Taxonomist, Herbarium of Medicinal, Aromatic Plant and Traditional Medicine Research Institute (MAPTRI), Khartoum, Sudan, and deposited in the herbarium of the Institute. Voucher specimen numbers for these plant species are given in Table 1 .

\section{Chemicals and equipment}

6-Hydroxy-2,5,7,8-tetramethylchroman-2-carboxylic acid (Trolox), 1,1-diphenyl-2-picrylhydrazyl (DPPH), dimethylsulfoxide (DMSO), disodium hydrogenphosphate 12-water, sodium dihydrogenphosphate dehydrate, Triton ${ }^{\odot} \mathrm{X}-100$, and Valinomycin were purchased from Wako Pure Chemical Industries, Ltd., Osaka, Japan. 4-Methylumbelliferyl oleate (4-MUFO) was purchased from Toronto Research Chemicals, Toronto, Ontario, Canada. Acarbose, $p$-nitrophenyl glucopyranoside (PNGP) and di-potassium hydrogenphosphate were purchased from Nacalai Tesque, Inc., Kyoto, Japan. $\alpha$-Glucosidase (from Sacharomyces cerevisiae), porcine pancreatic lipase (PPL, type II), and bovine serum albumin (BSA) were purchased from Sigma-Aldrich Co. (St. Louis, MO, USA). Cetilistat was purchased from Combi-Blocks, Inc., Japan. Potassium dihydrogen phosphate was purchased from Kanto Chemical Co., Inc. Tokyo, Japan, and 2-morpholinoethanesulfonic acid, monohydrate (MES) was purchased from Dojindo Chemical Research, Kumamoto, Japan. Paraformaldehyde was purchased from Chiyoda Inc. and HCS DNA Damage kit was purchased from Thermo Fisher Scientific Inc.

Absorbance was recorded on the Infinite $200 \mathrm{PRO}^{\circ}$ (Tecan Austria GmBH, Grodig, Austria) spectrophotometer (for DPPH and $\alpha$-Glucosidase inhibitory assays) and Wallac $\mathrm{ARVO}^{\mathrm{TM}}$ MX 1420 multilabel counter spectrophotometer (Perkin Elmer Japan, Kanagawa, Japan) (for lipase inhibitory assay).

\section{Preparation of plant extract}

About $20 \mathrm{~g}$ of each plant sample was ground and extracted with two different solvents (70\% aqueous ethanol and water) by the use of ultra-sonication assisted extraction at $50{ }^{\circ} \mathrm{C}$ for two hours. Both extracts were then filtered. $70 \%$ Ethanolic extracts were concentrated and evaporated under reduced pressure using rotatory evaporator. Whereas, water extracts were freeze-dried.

\section{DPPH free radical scavenging activity}

The free radical scavenging activity was measured according to the modified method of Shimamura et al. [27], One hundred $\mu \mathrm{L}$ of sample extract (in 50\% $(v / \mathrm{v})$ ethanol) with varying concentrations were mixed with $50 \mu \mathrm{L}$ of $200 \mathrm{mM}$ MES buffer $(\mathrm{pH} 6.0)$ and $50 \mu \mathrm{L}$ of $800 \mu \mathrm{M}$ DPPH in $99.5 \%$ ethanol solution. After that the assay plate was kept in dark at room temperature for 20 min, then the absorbance was measured at $520 \mathrm{~nm}$. Trolox was used as a positive control and the percentage radical scavenging capacity (SC\%) of samples was obtained from the following equation: 
$\mathrm{SC} \%=[(\mathrm{AC}-\mathrm{A} 0)-(\mathrm{AS}-\mathrm{A} 0) /(\mathrm{AC}-\mathrm{A} 0)] \times 100$, where $\mathrm{AC}$ is the absorbance of the control, which contained all reagents except test sample, A0 is absorbance of the blank which contained the sample and all reagents except $\mathrm{DPPH}$ and AS is the absorbance of the test samples. From these data, the $\mathrm{SC}_{50}$ value was calculated, which is defined as the concentration of the extract required for $50 \%$ reduction of the DPPH radical absorbance. All samples were assayed in triplicate.

\section{$a$-Glucosidase inhibitory activity}

$\alpha$-Glucosidase inhibitory activity was measured according to the method by Yang et al. [28] with slight modifications. Briefly, $10 \mu \mathrm{L}$ of the sample solution with varying concentrations was mixed with $60 \mu \mathrm{L}$ of phosphate buffer (200 mM pH 6.8) and $10 \mu \mathrm{L}$ of $\alpha$-glucosidase $(1 \mathrm{U} / \mathrm{ml})$ in phosphate buffer. After incubation at $37{ }^{\circ} \mathrm{C}$ for $5 \mathrm{~min}, 20 \mu \mathrm{L}$ of PNGP $(4 \mathrm{mM})$ was added to start enzyme reaction. The absorbance of the reaction solutions was measured right after the addition of substrate for $12 \mathrm{~min}$ at $405 \mathrm{~nm}$. Acarbose was used as the positive control. The percentage inhibition of $\alpha$-glucosidase activity was calculated via the following equation:

$\%$ inhibition $=[1-(\mathrm{AS}$ at $12 \mathrm{~min}-\mathrm{AS}$ at $0 \mathrm{~min}) /(\mathrm{AC}$ at $12 \mathrm{~min}-\mathrm{AC}$ at $0 \mathrm{~min})] \times 100$, where AS is the absorbance readings of samples, $\mathrm{AC}$ is the absorbance readings of the control which contain all solvents except the sample. The concentration of the tested samples giving 50\% inhibition of the enzyme activity $\left(\mathrm{IC}_{50}\right)$ was estimated from the plots of the concentration vs. the inhibitory activity, all samples were assayed in triplicate.

\section{Lipase inhibitory activity}

Porcine pancreatic lipase inhibitory activity was measured according to the modified method of Bitou et al. [29], the assay was performed using 96-well microplate. Briefly, the reaction mixture was prepared with $50 \mu \mathrm{L}$ of porcine pancreatic lipase $(50 \mathrm{U} / \mathrm{ml})$ dissolved in phosphate buffer (200 mM pH 7.4), and $50 \mu \mathrm{L}$ sample solution with varying concentrations and left at room temperature for $10 \mathrm{~min}$. The reaction was started by adding $100 \mu \mathrm{L}$ of $0.5 \mathrm{mM}$ 4-MUFO diluted in phosphate buffer (0.2 M pH 7.4) from $0.1 \mathrm{M}$ stock solution in DMSO. The amount of 4-methylumbelliferone released by enzyme reaction was measured fluorometrically at an excitation wavelength of $355 \mathrm{~nm}$ and an emission wavelength of $460 \mathrm{~nm}$ for $8 \mathrm{~min}$. Cetilistat was used as the positive control. The relative lipase inhibition activity was calculated using the following formula:

$\%$ Inhibition $=[1-(\mathrm{FS}$ at $8 \mathrm{~min}-\mathrm{FS}$ at $0 \mathrm{~min}) /(\mathrm{FC}$ at $8 \mathrm{~min}-\mathrm{FC}$ at $0 \mathrm{~min})] \times 100$, where $\mathrm{FS}$ is the fluorescence readings of samples which contain all solvents and sample and FC is the control which contains all solvent but the sample. The concentration of the tested samples giving $50 \%$ inhibition of the enzyme activity $\left(\mathrm{IC}_{50}\right)$ was estimated from the plots of the concentration vs. the inhibitory activity, all samples were assayed in triplicate.

\section{Cell culture}

The HeLa cell line was cultured in Dulbecco's Modified Eagle's medium (DMEM) supplemented with $10 \%$ fetal calf serum (FCS). The cells were maintained at $37{ }^{\circ} \mathrm{C}$ in a $\mathrm{CO}_{2}$ incubator with $90 \%$ humidity and $5 \% \mathrm{CO}_{2}$. Cells were subcultured regularly using trypsin/EDTA.

\section{Cell genotoxicity/cytotoxicity assay using the HCS DNA damage kit}

HeLa cells were seeded at a density of 7500 cells $/ 100 \mu \mathrm{L}$ /well on 96-well plate. After $24 \mathrm{~h}$ incubation, $100 \mu \mathrm{L}$ of the plant extracts with different concentrations was added to cells along with the control drug (Valinomycin) and incubated for $24 \mathrm{~h}$. Treated cells were then stained by adding $50 \mu \mathrm{L}$ of Image-iT ${ }^{\bullet}$ Dead Green ${ }^{\text {Tx }}$ viability stain and incubated for $30 \mathrm{~min}$. Then the medium was removed and cells were fixed, permeabilized and blocked by incubation with $4 \%$ paraformaldehyde, Triton ${ }^{\circ} \mathrm{X}-100$ in PBS and bovine serum albumin (BSA) in PBS solutions, respectively. Cells were then incubated with $50 \mu \mathrm{L}$ of $\mathrm{pH} 2 \mathrm{AX}$ mouse monoclonal primary antibody solution for $1 \mathrm{~h}$ at room temperature. After washing in

Table 2 Percentage extraction yield of the plants included in the study

\begin{tabular}{lll}
\hline Scientific name & Extraction yield (\%) & \\
\cline { 2 - 3 } & $70 \%$ Ethanol extract & Water extract \\
\hline A. precatorius & 9.6 & 11.8 \\
A. nilotica & 27.9 & 29.2 \\
B. linarifolia & 7.6 & 8.0 \\
B. papyrifera & 34.3 & 33.2 \\
C. ipecacuanha & 10.6 & 11.4 \\
C. colocynthis & 4.1 & 9.8 \\
C. sinensis & 11.4 & 12.2 \\
C. proximus & 5.8 & 5.0 \\
C. rotundus. & 5.5 & 2.2 \\
G. alata & 10.1 & 11.6 \\
M. annua & 2.4 & 2.4 \\
P. glaucum & 5.1 & 5.4 \\
R. graveolens & 24.3 & 21.6 \\
S. argel & 20.2 & 15.0 \\
T. bakis & 9.4 & 8.9 \\
T. foenum-graceum & 13.7 & 11.8 \\
V. madagascariensis & 28.5 & 35.8 \\
Z. spina-christi & 19.9 & 16.6 \\
\hline \% extration & &
\end{tabular}

\% extraction yield is expressed as $w / \mathrm{w} \mathrm{g}$ of dried extract 
PBS solution three times, Cells were further incubated with $50 \mu \mathrm{L}$ of Alexa Fluor 555 goat anti-mouse IgG $(\mathrm{H}+\mathrm{L})$-conjugated secondary antibody and Hoechst 33342 nuclear counterstain solution for $1 \mathrm{~h}$ in dark. Then washed with PBS solution three times and $100 \mu \mathrm{L}$ of PBS was added. Stained cells were observed using Keyence BZ-X700 (Keyence, Japan).

\section{Statistical analysis}

For quantitative analysis, the result represents the mean \pm SD $(n=3)$ and the data were analyzed using the Scheffe's test by a Statview software as indicated in each figure legend. The level of significance was set at $p<0.05$.

\section{Results}

\section{Extraction yield}

The extraction yield (\%) of the 18 Sudanese medicinal plants using $70 \%$ ethanol and water as solvents is shown in Table 2.

\section{Free radical scavenging activity}

In the present study, DPPH radical scavenging assay was used to evaluate the in vitro antioxidant activity for all plant extracts. Results are presented as $\mathrm{SC}_{50}$, the lower $\mathrm{SC}_{50}$ values indicate the stronger antioxidant activity

Table 3 DPPH radical scavenging activity of extracts

\begin{tabular}{lll}
\hline Scientific name & \multicolumn{2}{l}{$\begin{array}{l}\mathrm{SC}_{50}(\mu \mathrm{g} / \mathrm{ml})^{\mathrm{a}} \text { value for DPPH radical } \\
\text { scavenging activity }\end{array}$} \\
\cline { 2 - 3 } $70 \%$ Ethanol extract & Water extract \\
\hline A. precatorius & $13.66 \pm 0.12$ & $20.93 \pm 3.54$ \\
A. nilotica & $4.06 \pm 0.09$ & $7.51 \pm 0.19$ \\
B. linariifolia & $105.05 \pm 2.59$ & $336.73 \pm 4.49$ \\
B. papyrifera & $120.53 \pm 3.09$ & $301.53 \pm 0.48$ \\
C. ipecacuanha & $251.28 \pm 4.57$ & $359.18 \pm 2.89$ \\
C. colocynthis & $507.67 \pm 8.69$ & $698.20 \pm 9.68$ \\
C. sinensis & $316.24 \pm 8.83$ & $301.5 \pm 10.91$ \\
C. proximus & $201.88 \pm 0.03$ & $333.99 \pm 3.54$ \\
C. rotundus. & $142.23 \pm 5.88$ & $270.64 \pm 9.62$ \\
G. alata & $73.68 \pm 3.11$ & $137.66 \pm 1.31$ \\
M. annua & $31.65 \pm 0.69$ & $281.94 \pm 2.65$ \\
P. glaucum & $127.84 \pm 5.14$ & $257.19 \pm 2.08$ \\
R. graveolens & $187.24 \pm 1.50$ & $362.04 \pm 0.93$ \\
S. argel & $334.35 \pm 6.01$ & $411.42 \pm 7.03$ \\
T. bakis & $278.04 \pm 3.92$ & $438.37 \pm 2.99$ \\
T. foenum-graceum & $285.58 \pm 2.22$ & $455.84 \pm 4.69$ \\
V. madagascariensis & $463.87 \pm 5.21$ & $552.27 \pm 11.86$ \\
Z. spina-christi & $10.75 \pm 0.08$ & $36.01 \pm 3.60$ \\
Trolox & $11.35 \pm 0.05$ & \\
\hline E. & & \\
& &
\end{tabular}

${ }^{\mathrm{a} E a c h}$ value represents the mean $\pm \mathrm{SD}(n=3)$

${ }^{\mathrm{b}}$ Trolox was used as a positive control
(Table 3). Trolox, a water-soluble derivative of vitamin $\mathrm{E}$ was used as positive control, with an $\mathrm{SC}_{50}$ value of $11.35 \pm 0.05 \mu \mathrm{g} / \mathrm{ml}$. These results showed that both extracts of A. nilotica exhibited the highest antioxidant activity among extracts. Furthermore, $70 \%$ ethanol and water extracts of $A$. nilotica were more active than the positive control Trolox with $\mathrm{SC}_{50}$ values of $4.06 \pm 0.09$ and $7.51 \pm 0.19 \mu \mathrm{g} / \mathrm{ml}$, respectively. Approximately, similar scavenging activity as the positive control was shown by the ethanolic extracts of $Z$. spina-christi and $A$. precatorius, with $\mathrm{SC}_{50}$ values of $10.75 \pm 0.08$ and $13.66 \pm$ $0.12 \mu \mathrm{g} / \mathrm{ml}$, respectively. For the ethanolic extracts of $M$. annua and G. alata, the scavenging ability was moderate compared to the positive control, with $\mathrm{SC}_{50}$ values of $31.65 \pm 0.69$ and $73.68 \pm 3.11 \mu \mathrm{g} / \mathrm{ml}$, respectively. On the other hand, the free radical scavenging activity of the water extracts of A. precatorius, Z. spina-christi and G. alata, was less potent with $\mathrm{SC}_{50}$ values of $20.93 \pm 3.54$, $36.01 \pm 3.60$ and $137.66 \pm 1.31 \mu \mathrm{g} / \mathrm{ml}$, respectively.

\section{$a$-Glucosidase inhibitory activity}

In this study, we aimed to explore $\alpha$-glucosidase inhibitors of plant origin. Thus, we investigated the inhibitory effect of thirty-six ethanolic and water extracts on $\alpha$-glucosidase enzyme obtained from Saccharomyces cerevisiae. Table 4
Table 4 a-glucosidase inhibitory activity of extracts

\begin{tabular}{|c|c|c|}
\hline \multirow[t]{2}{*}{ Scientific name } & \multicolumn{2}{|c|}{$\mid \mathrm{C}_{50}(\mu \mathrm{g} / \mathrm{m} \mid)^{\mathrm{a}}$ value for $a$-glucosidase inhibition } \\
\hline & $70 \%$ Ethanol extract & Water extract \\
\hline A. precatorius & - & - \\
\hline A. nilotica & $3.75 \pm 0.62$ & $1.33 \pm 0.57$ \\
\hline B. linariifolia & - & - \\
\hline B. papyrifera & $141.57 \pm 1.54$ & - \\
\hline C. ipecacuanha & - & - \\
\hline C. colocynthis & - & - \\
\hline C. sinensis & - & $265.66 \pm 5.13$ \\
\hline C. proximus & - & $282.37 \pm 7.26$ \\
\hline C. rotundus. & $118.92 \pm 1.01$ & - \\
\hline G. alata & $191.66 \pm 16.07$ & $623.99 \pm 22.54$ \\
\hline M. annua & $78.78 \pm 3.19$ & - \\
\hline P. glaucum & - & - \\
\hline R. graveolens & $162.09 \pm 52.08$ & - \\
\hline S. argel & - & - \\
\hline T. bakis & - & - \\
\hline T. foenum-graceum & - & - \\
\hline V. madagascariensis & - & - \\
\hline Z. spina-christi & $3.35 \pm 0.61$ & $5.49 \pm 0.50$ \\
\hline Acarbose $^{b}$ & $240.00 \pm 0.03$ & \\
\hline
\end{tabular}

${ }^{a}$ Each value represents the mean \pm SD $(n=3)$

${ }^{\mathrm{b}}$ Acarbose was used as a positive control 
shows the results of the in vitro assay of $\alpha$-glucosidase inhibitory activity for all extracts. Acarbose was used as a positive control in this assay $\left(\mathrm{IC}_{50}=240.00 \pm 0.03 \mu \mathrm{g} / \mathrm{ml}\right)$. It was noted that $70 \%$ ethanolic extracts had higher inhibitory activity as compared to their corresponding water extracts. Our results demonstrated that the highest potential $\alpha$-glucosidase inhibitory activity was shown by the ethanolic and water extracts of $A$. nilotica and $Z$. spina-christi with $\mathrm{IC}_{50}$ values ranging between $1.0-5.0 \mu \mathrm{g} / \mathrm{ml}$, which were significantly higher than that of the positive control, Acarbose. In addition, the ethanolic extract of $M$. annua, C. rotundus, B. papyrifera and G. alata demonstrated strong enzymatic inhibition with $\mathrm{IC}_{50}$ values of $78.78 \pm 3.19$, $118.92 \pm 1.01,141.57 \pm 1.54$ and $191.66 \pm 16.07 \mu \mathrm{g} / \mathrm{ml}$, respectively. In case of water extract, $C$. sinensis, $C$. proximus and G. alata, had a slightly lower inhibitory activity compared to Acarbose with $\mathrm{IC}_{50}$ values of $260.0 \pm 0.06,280.0 \pm$ 0.06 and $610.0 \pm 0.02 \mu \mathrm{g} / \mathrm{ml}$, respectively. Interestingly, $C$. sinensis and $C$. proximus were found to have their activity only in water extract, which may support their traditional use as antidiabetic agents.

\section{Lipase inhibitory activity}

In the current study, pancreatic lipase inhibitory activity was evaluated for all extracts, using Cetilistat as a positive control, with the $\mathrm{IC}_{50}$ value of $4.66 \pm 0.05 \mu \mathrm{g} / \mathrm{ml}$ (Table 5). While the majority of the extracts demonstrated some extent of inhibitory activity against lipase enzyme, some of the plant extracts were particularly active. The ethanolic extracts of A. nilotica, Z. spina-christi, S. argel, $M$. annua and B. papyrifera exhibited a stronger inhibitory activity against pancreatic lipase enzyme compared to Cetilistat, with $\mathrm{IC}_{50}$ values of $1.65 \pm 0.02,1.86 \pm 0.07,2.12 \pm 0.08$, $4.22 \pm 0.08$ and $4.33 \pm 0.07 \mu \mathrm{g} / \mathrm{ml}$, respectively. Moreover, the water extracts of $A$. nilotica, $Z$. spina-christi and $C$. sinensis had a strong lipase inhibitory activity with $\mathrm{IC}_{50}$ values of $0.31 \pm 0.01,0.72 \pm 0.01$ and $4.51 \pm 0.08 \mu \mathrm{g} / \mathrm{ml}$, respectively.

\section{Cell genotoxicity/cytotoxicity activity}

Based on the above results of the bioactivities screening; the $70 \%$ ethanol and water extracts of A. nilotica, $Z$. spina-christi, $M$. апnua, $A$. precatorius, and $G$. alata were investigated for potential genotoxicity and cytotoxicity on HeLa cell line using HCS DNA Damage assay at various concentrations $(2 \mu \mathrm{g} / \mathrm{ml}, 20 \mu \mathrm{g} / \mathrm{ml}$, and $200 \mu \mathrm{g} /$ ml) (Fig. 1a). As shown in Fig. 1b, the $70 \%$ ethanol extracts of A. nilotica, Z. spina-christi, and M. annua showed genotoxicity at concentrations $>20 \mu \mathrm{g} / \mathrm{ml}$. In addition, a significant level of genotoxicity was observed at concentrations $>20 \mu \mathrm{g} / \mathrm{ml}$ for the water extracts of $Z$. spina-christi and $2 \mu \mathrm{g} / \mathrm{ml}$ for the water extracts of $A$. precatorius. Whereas, water extract of $A$. nilotica showed genotoxicity at concentrations $>20 \mu \mathrm{g} / \mathrm{ml}$ (Fig. 1c).
Table 5 Pancreatic lipase inhibitory activity of extracts

\begin{tabular}{lll}
\hline Scientific name & \multicolumn{2}{l}{$\mid \mathrm{C}_{50}(\mathrm{\mu g} / \mathrm{m})^{\mathrm{a}}$ value for pancereatic lipase inhibition } \\
\cline { 2 - 3 } & $70 \%$ Ethanol extract & Water extract \\
\hline A. precatorius & $17.55 \pm 1.36$ & $27.46 \pm 1.58$ \\
A. nilotica & $1.65 \pm 0.02$ & $0.31 \pm 0.01$ \\
B. linariifolia & $16.78 \pm 0.31$ & $18.12 \pm 0.27$ \\
B. papyrifera & $4.33 \pm 0.07$ & $46.19 \pm 1.21$ \\
C. ipecacuanha & $8.23 \pm 0.12$ & $22.1 \pm 0.77$ \\
C. colocynthis & $63.56 \pm 1.6$ & $20.66 \pm 1.04$ \\
C. sinensis & $29.82 \pm 0.22$ & $4.51 \pm 0.08$ \\
C. proximus & $16.69 \pm 0.52$ & $18.43 \pm 0.28$ \\
C. rotundus. & $8.16 \pm 0.17$ & $5.38 \pm 0.42$ \\
G. alata & $19.99 \pm 0.77$ & $23.76 \pm 0.26$ \\
M. annua & $4.22 \pm 0.08$ & $9.28 \pm 1.81^{*}$ \\
P. glaucum & $119.91 \pm 2.78$ & $19.58 \pm 0.17$ \\
R. graveolens & $9.37 \pm 0.42$ & $48.03 \pm 1.38$ \\
S. argel & $2.12 \pm 0.08$ & $33.96 \pm 0.29$ \\
T. bakis & $17.75 \pm 0.27$ & $60.38 \pm 0.88$ \\
T. foenum-graceum & $244.15 \pm 1.80$ & $51.86 \pm 2.67$ \\
V. madagascariensis & $35.10 \pm 5.56$ & $98.66 \pm 3.60$ \\
Z. spina-christi & $1.86 \pm 0.07$ & $0.72 \pm 0.01$ \\
Cetilistat & $4.66 \pm 0.05$ & \\
\hline
\end{tabular}

${ }^{a}$ Each value represents the mean $\pm \mathrm{SD}(n=3)$

${ }^{\mathrm{b}}$ Cetilistat was used as a positive control of lipase inhibitory activity

On the other hand, results showed a significant level of cytotoxicity in terms of depressing the HeLa cell viability of the $70 \%$ ethanol extracts of A. nilotica $(200 \mu \mathrm{g} / \mathrm{ml}), Z$. spina-christi $(200 \mu \mathrm{g} / \mathrm{ml})$, G. alata $(200 \mu \mathrm{g} / \mathrm{ml})$, M. annua $(2,20,200 \mu \mathrm{g} / \mathrm{ml})$, and A. precatorius $(200 \mu \mathrm{g} / \mathrm{ml})$. Similarly, the water extracts of $A$. nilotica $(2,20,200 \mu \mathrm{g} / \mathrm{ml})$, G. alata $(200 \mu \mathrm{g} / \mathrm{ml})$, M. апnиа $(20,200 \mu \mathrm{g} / \mathrm{ml})$ and $A$. precatorius $(2,20,200 \mu \mathrm{g} / \mathrm{ml})$ exhibited a significant level of cytotoxicity as well (Fig. 2).

\section{Discussion}

The increasing reliance on traditional herbal medicines as an approach to therapy has been observed worldwide. Herbal remedies are prepared traditionally as macerates, potions or decoctions using water as a solvent and given either as a mixture or as a single medicinal plant [10]. However, the use of these herbal remedies and medicinal plants without scientific validation of their claimed activity can be harmful and sometimes fatal. Accordingly, we designed this study with the aim of discovering potential and safe antidiabetic agents from plant origin and to validate the traditional uses of these plants as antidiabetic medicines.

In the current study, different parts of eighteen Sudanese medicinal plants were selected according to their traditional uses (Table 1), many of which are commonly used by Sudanese people to treat different ailments, including 
A

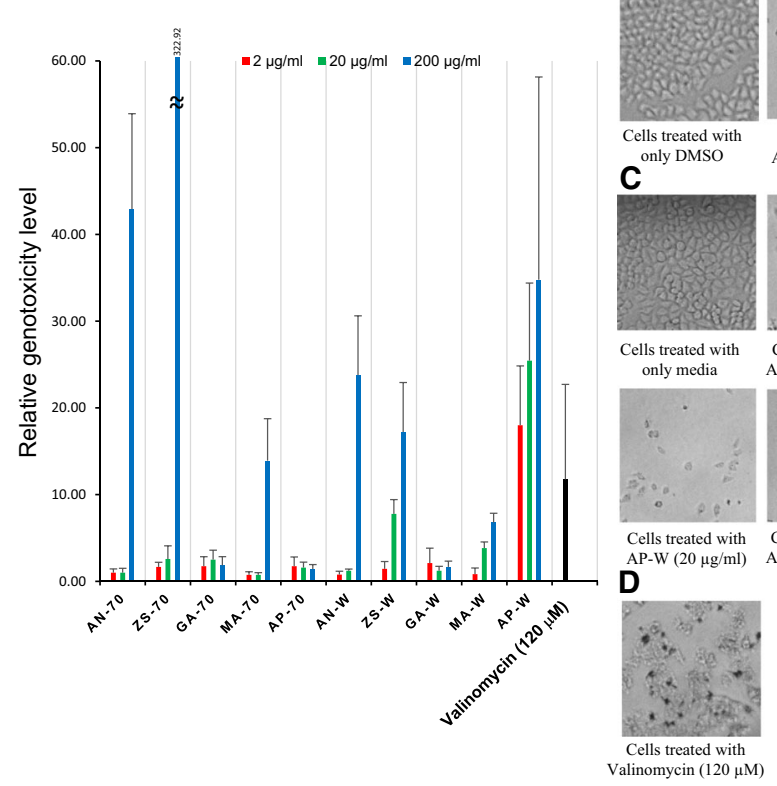

B
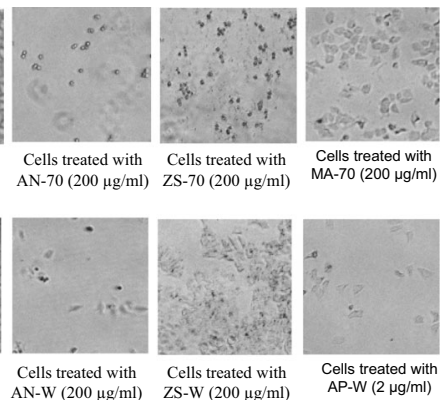
$\begin{array}{ccc}\text { Cells treated with } & \text { Cells treated with } & \text { Cells treated with } \\ \mathrm{AN}-\mathrm{W}(200 \mu \mathrm{g} / \mathrm{ml}) & \mathrm{ZS}-\mathrm{W}(200 \mu \mathrm{g} / \mathrm{ml}) & \text { AP-W }(2 \mu \mathrm{g} / \mathrm{ml})\end{array}$

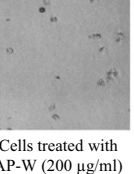

Fig. 1 Imaging of genotoxicity of Sudanese medicinal plants in HeLa cells using the HCS DNA Damage Kit, (a) Chart showing the relative genotoxicity level of the 70\% ethanol and water extracts of five Sudanese medicinal plants (AN: Acacia nilotica, ZS: Ziziphus spina-christi, GA: Geigeria alata. MA: Martynia annua AP: Abrus precatorius; For each extract, 70 represents 70\% EtOH extract and W represents water extract), (b) Cells treated with $70 \%$ ethanolic extracts; (c) Cells treated with water extracts; (d) Positive control experiment, HeLa cells were treated with $120 \mu \mathrm{M}$ valinomycin for $24 \mathrm{~h}$ at $37^{\circ} \mathrm{C} / 5 \% \mathrm{CO}_{2}$. Imaging and analysis were performed using a BZ-X700. At $120 \mu \mathrm{M}$ valinomycin, cells showed genotoxic effects as demonstrated by the positive pH2AX. The level of genotoxicity in the control experiment was set as 1.0. The fold change in signal between treated samples and control was $>3$-fold for a parameter indicating genotoxicity

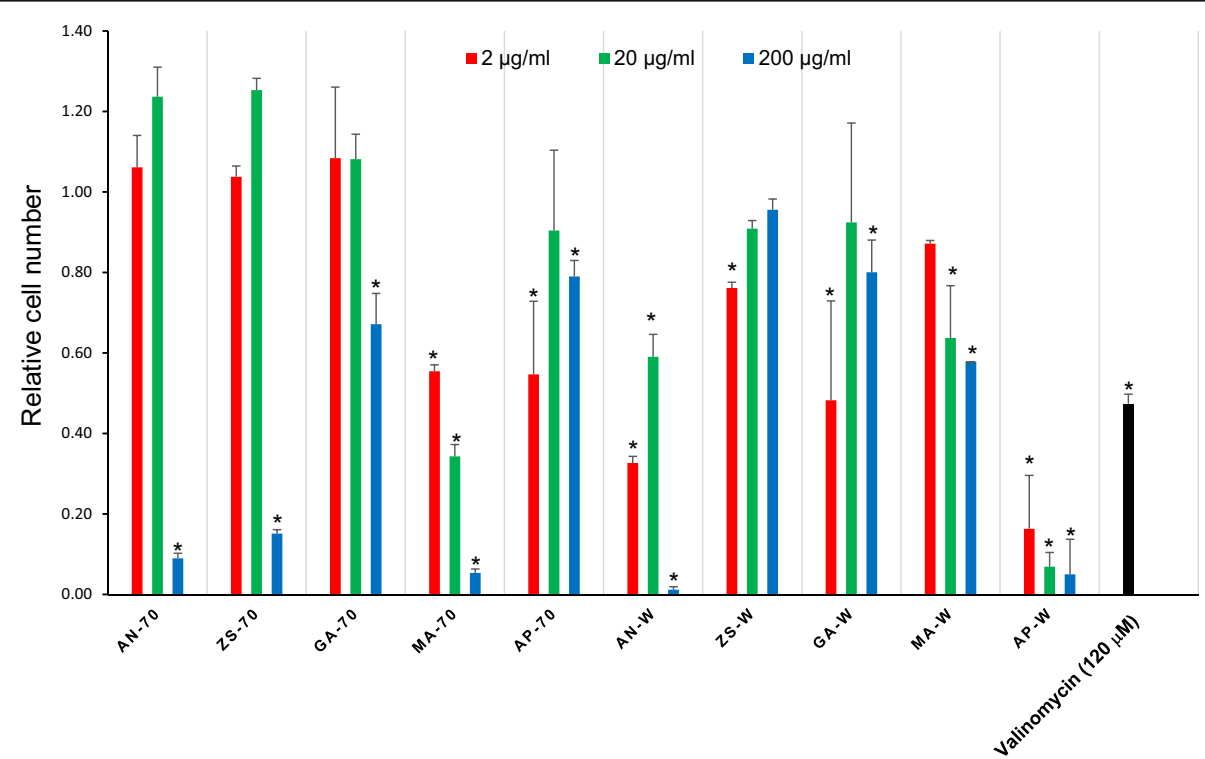

Fig. 2 Imaging of cytotoxicity of Sudanese medicinal plants in HeLa cells using the HCS DNA Damage Kit. AN: Acacia nilotica, ZS: Ziziphus spina-christi, GA: Geigeria alata. MA: Martynia annua AP: Abrus precatorius; For each extract, 70 represents $70 \% \mathrm{EtOH}$ extract and W represents water extract. As a control experiment, HeLa cells were treated with $120 \mu \mathrm{M}$ valinomycin for $24 \mathrm{~h}$ at $37^{\circ} \mathrm{C} / 5 \% \mathrm{CO}_{2}$. Imaging and analysis were performed using a BZ-X700. At $120 \mu \mathrm{M}$ valinomycin, cells showed cytotoxic effects as demonstrated by the positive Image-iT ${ }^{\oplus}$ DEAD Green ${ }^{T M}$ viability stain fluorescence 
diabetes mellitus. Two solvents were used for extracting plant samples, $70 \%$ ethanol and water, which plays an important role in isolating different phytochemical from the plant and consequently different activities will be obtained $[25,30]$. The use of solvents of different polarities has a direct association with the percentage yield of the extract. It was noted that the yield percentage of water extracted samples was relatively higher than that of $70 \%$ ethanol, which may be attributed to the higher solubility of carbohydrates and proteins in water than in ethanol [31]. Thereafter, the obtained extracts were screened for their potential antioxidant activity as well as, $\alpha$-glucosidase inhibitory and pancreatic lipase inhibitory activities.

Oxidative stress occurs when production of oxidants or reactive oxygen species (ROS) exceeds local antioxidant capacity and it is thought to be associated with the pathogenesis of many diseases including diabetes mellitus [32]. Antioxidants are molecules that decelerate or quench free radical reactions and hence, delay or prevent cellular damage [33]. Medicinal plants are rich sources of secondary metabolites that act as natural antioxidant such as phenolic compounds (cinnamic acids, benzoic acids, flavonoids, proanthocyanidins, stilbenes, coumarins, lignans, and lignins), ascorbic acid and carotenoids [34, 35]. According to our results, A. nilotica showed the most potent antioxidant activity among other tested plants. There are several phytochemical studies on the pods of $A$. nilotica, revealed the presence of various polyphenolic compounds, such as isoquercetin, rutin, leucocyanidin, different galloylated derivatives of catechin, which possess free radical scavenging properties [36, 37]. Furthermore, the ethanolic extracts of $Z$. spina-christi and $A$. precatorius had relatively similar activity as the positive control, which is consistent with previous phytochemical studies that reported the presence of polyphenols, flavonoids, and tannins in both species and can be responsible for their potent antioxidant activities as well $[38,39]$. Similarly, the ethanolic extracts of $M$. апnиa and G. alata, had moderate free radical scavenging activities. Kenwat et al. (2014) investigated the phytoconstituents of fruit oil of $M$. апnиa and reported the presence of flavonoids, tannins and phenolic compounds that may be attributed to the plant antioxidant activity [40]. To the best of our knowledge, this is the first screening study on $M$. апnua species from Sudan [41]. A recent study by Zheleva-Dimitrova et al. (2016) investigated the phenolic acids contents of $G$. alata roots and leaves and identified chlorogenic acids that revealed antioxidant potentials [42]. Notably, the extracts obtained using $70 \%$ ethanol, illustrated stronger radical scavenging capacity than water extracts, which may be due to the ability of the organic/aqueous solvent to extract more phenolic compounds (a higher number of hydroxyl groups) that possess antioxidant activity, than extraction with water alone. Do et al. (2014) has reported a similar effect of extraction solvents on the radical scavenging activity, with stronger antioxidant activity in ethanolic/aqueous extracts compared to water extracts [43].

Oral antidiabetic (hypoglycemic) drugs such as Acarbose act by competitive and reversible inhibition of intestinal $\alpha$-glucosidases, which slows down carbohydrate digestion and thus leads to a reduction of postprandial blood glucose levels [44]. As mentioned above, the strongest $\alpha$-glucosidase inhibitory activity was shown by A. nilotica extracts. On the basis of the previous reports, it is possible that the presence of polyphenols, flavonoids, and tannins are responsible for the observed antidiabetic activity. Our results are also consistent with the in vivo study on the therapeutic effect of A. nilotica pod on diabetic rats, Enayat et al. (2012) has reported a significant reduction in blood glucose levels in the A. nilotica treated group in comparison to diabetic control rats [45], which support the $\alpha$-glucosidase inhibitory activity of A. nilotica as a mechanism of lowering blood glucose levels. In addition, the strong $\alpha$-glucosidase inhibitory activity of the ethanolic extract of $M$. annua, and $G$. alata suggest a correlation with their antioxidant activities due to the presence of bioactive compounds. For the best of our knowledge, it is the first report of the $\alpha$-glucosidase inhibitory activity of the fruit of $M$. annua.

Inhibitors of pancreatic lipase such as Cetilistat, act by diminishing the absorption of dietary fats. Many reported secondary metabolites in plants, have already shown profound inhibition of pancreatic lipase enzyme such as phenolics, glycosides, saponins, and terpenes [46]. Our results showed that the majority of the tested extracts demonstrated some extent of inhibitory activity against lipase enzyme, particularly the extracts of $A$. nilotica and $Z$. spina-christi. This strongly suggests that these plants can be a source of potential leads for pancreatic lipase inhibition in order to treat and/or prevent obesity and other lifestyle-related diseases.

Prominently, during the evaluation of the bioactivities of the crude extracts, it is crucially important to consider the cytotoxicity testing of the bioactive extracts to exclude the toxic compounds that can impediment their therapeutic indications [47]. In the current study, 10 bioactive extracts from 5 plants species namely; A. nilotica, $Z$. spina-christi, M. annua, A. precatorius, and G. alata were selected for further investigations of their genotoxicity and cytotoxicity on HeLa cell line. Regarding the genotoxicity effect in comparison with the antioxidant activity, the $\mathrm{IC}_{50}$ values of $A$. nilotica and G. alata were non-genotoxic for both extracts along with the ethanolic extracts of A. precatorius and Z. spina-christi. Contrarily, the ethanolic extracts of $M$. annua and the water extracts of $A$. precatorius and $Z$. spina-christi were 
considered as genotoxic at their $\mathrm{IC}_{50}$ concentrations. Furthermore, A. nilotica and Z. spina-christi extracts were considered to be non-cytotoxic at their $\mathrm{IC}_{50}$ concentrations, in addition to the ethanolic extract of $A$. precatorius and the water extract of G. alata. In contrast, the ethanolic extracts G. alata and M. annua, along with the water extract of $A$. precatorius were found to be cytotoxic for HeLa cells at their activity concentrations.

On the other hand, in comparison with the $\mathrm{IC}_{50}$ values of the $\alpha$-glucosidase inhibitory and lipase inhibitory activities of the extracts, it was found that both extracts of A. nilotica along with the ethanolic extract of $Z$. spina-christi were found to be non-genotoxic and non-cytotoxic at their $\mathrm{IC}_{50}$ values, which support the use of these bioactive crude extracts as safe anti-diabetic agents. Consequently, these findings recommend the use of these bioactive crude extracts as antioxidant, anti-diabetic, and anti-obesity agents under consideration to their toxicity levels. In addition, it necessitates further investigations for the bioactive extracts to identify the responsible compounds for the observed antioxidant, $\alpha$ glucosidase, and lipase inhibitory activities.

\section{Conclusion}

In the present study, eighteen of the Sudanese medicinal plants were screened for their potential antioxidant activity, $\alpha$-glucosidase inhibitory and porcine pancreatic lipase inhibitory activities. Based upon the results, it could be concluded that Acacia nilotica, Ziziphus spina-christi, Geigeria alata, Martynia annua, Abrus precatorius, Cordia sinensis and Boswellia papyrifera exhibited an appreciable range of activity on the tested bioactivities, which highlights and supports their potential use as natural antidiabetic agents with strong antioxidant and anti-hyperlipidemic effects. Moreover, the genotoxicity and cytotoxicity assay findings suggest that although some of the tested bioactive extracts can be cytotoxic and/or genotoxic, however, their use within the safe concentration limits or as pure bioactive compounds can be of great benefit therapeutically. Our results will be a guide for the selection of plant species for further investigation in the discovery of new bioactive compounds from natural origin. Further supportive studies in chemical isolation and animal model experiments can be performed to confirm the in vitro antioxidant and enzymatic inhibition activities of the extracts.

\section{Abbreviations \\ 4-MUFO: 4-methylumbelliferyl oleate; DMEM: Dulbecco's Modified Eagle's medium; DMSO: Dimethylsulfoxide; DPPH: 1,1-diphenyl-2-picrylhydrazyl; FCS: Fetal calf serum, BSA: Bovine serum albumin; MES: 2-morpholinoethanesulfonic acid, mono hydrate; PNGP: P-nitrophenyl glucopyranoside; PPL: Porcine pancreatic lipase; ROS: Reactive oxygen species}

\section{Acknowledgments}

The authors would like to thank Mr. Yahya Suleiman Mohamed, Taxonomist, Medicinal Aromatic Plants and Traditional Medicine Research Institute (MAPTRI), Khartoum, Sudan, for identification of the plant specimens. We are grateful to K. Matsuda (Keyence) for excellent technical assistance in immunofluorescence analysis.

\section{Funding}

This work was supported in part by Program for Leading Graduate Schools, Health life science: Interdisciplinary and Glocal Oriented (HIGO) Program, MEXT, Japan and Program for Building Regional Innovation Ecosystems at Kumamoto University, Japan for the collection of plant materials and reagents.

Availability of data and materials

Data and materials are available from the authors on reasonable request.

\section{Authors' contributions}

SMIE, HPD and TW designed the study. SMIE and TW collected the plant materials. SMIE, HPD, MW, NK and MM performed the experimental analysis. SMIE, HPD, MW, NK, MM, TS and SM performed the interpretation of data and wrote the initial draft. SMIE, HPD, SM and HK revised the manuscript. All authors read and approved the final manuscript.

Ethics approval and consent to participate

Not applicable.

Consent for publication

Not applicable.

Competing interests

The authors declare that they have no competing interests.

\section{Publisher's Note}

Springer Nature remains neutral with regard to jurisdictional claims in published maps and institutional affiliations.

\section{Author details}

${ }^{1}$ Department of Medicinal Botany, Graduate School of Pharmaceutical Sciences, Kumamoto University, 5-1 Oe-honmachi, Chuo-ku, Kumamoto, Kumamoto 862-0973, Japan. ${ }^{2}$ Program for Leading Graduate Schools, Health Life Science: Interdisciplinary and Glocal Oriented (HIGO) Program, Kumamoto University, Kumamoto, Japan. ${ }^{3}$ School of Pharmacy, Kumamoto University, 5-1 Oe-honmachi, Chuo-ku, Kumamoto, Kumamoto 862-0973, Japan. ${ }^{4}$ Department of Environmental and Molecular Health Sciences, Faculty of Medical and Pharmaceutical Sciences, Kumamoto University, Kumamoto 862-0973, Japan. ${ }^{5}$ Department of Molecular Medicine, Faculty of Medical and Pharmaceutical Sciences, Kumamoto University, Kumamoto 862-0973, Japan.

Received: 15 March 2018 Accepted: 4 October 2018

Published online: 19 October 2018

\section{References}

1. American Diabetes Association. Diagnosis and classification of diabetes mellitus. Diabetes Care. 2014;37:581-90.

2. World Health Organization (WHO). Global report on diabetes. Geneva: World Health Organization; 2016.

3. NCD Risk Factor Collaboration. Worldwide trends in diabetes since 1980: a pooled analysis of 751 population-based studies with $\mathbf{4} \cdot 4$ million participants. Lancet. 2016:387:1513-30.

4. International Diabetes Federation (IDF). IDF diabetes atlas 8th ed. Brussels: International Diabetes Federation; 2017.

5. Elrayah-Eliadarous HA, Östenson CG, Eltom M, Johansson P, Sparring V, Wahlström R. Economic and social impact of diabetes mellitus in a lowincome country: a case-control study in Sudan. J Diabetes. 2017;12:1082-90.

6. World Health Organization (WHO). Noncommunicable diseases country profiles 2014. Web site wwwwhoint/nmh/publications/ncd-profiles-2014/ en/. 2014

7. Shigidi $\mathrm{M}$, Abdelgafar $\mathrm{H}$. Awareness regarding diabetes control and diabetic nephropathy among Sudanese adults admitted with diabetic foot: a crosssectional study. Pan Afr Med J. 2013;16:157.

8. Balla SA, Ali KM, Mohamed HAA, Awadelkareem MA, Belal AA. Perception of educators about quality of diabetes education Services at Primary Health Care Level in Khartoum state, Sudan. Br J Med Med Res. 2016;14:1-8. 
9. Pandey A, Tripathi P, Pandey R, Srivatava R, Goswami S. Alternative therapies useful in the management of diabetes: a systematic review. J Pharm Bioallied Sci. 2011;3:504.

10. El Safi A Traditional Sudanese medicine: a primer for health care providers, researchers, and students: AZZA house; 2007.

11. Sabu M, Kuttan R. Anti-diabetic activity of medicinal plants and its relationship with their antioxidant property. J Ethnopharmacol. 2002;81:155-60.

12. Van den Oever IA, Raterman HG, Nurmohamed MT, Simsek S. Endothelial dysfunction, inflammation, and apoptosis in diabetes mellitus. Mediat Inflamm. 2010;2010.

13. Son SM. Reactive oxygen and nitrogen species in pathogenesis of vascular complications of diabetes. Diabetes Metabo J. 2012;36:190-8

14. Preston $\mathrm{SH}$, Stokes A. Obesity paradox: conditioning on disease enhances biases in estimating the mortality risks of obesity. Epidemiology. 2014;25:454

15. Buchholz T, Melzig MF. Medicinal plants traditionally used for treatment of obesity and diabetes mellitus-screening for pancreatic lipase and a-amylase inhibition. Phytother Res. 2016;30:260-6.

16. Kumar S, Narwal S, Kumar V, Prakash O. a-Glucosidase inhibitors from plants: a natural approach to treat diabetes. Pharmacogn Rev. 2011:5:19.

17. Khalid H, Abdalla WE, Abdelgadir H, Opatz T, Efferth T. Gems from traditional north-African medicine: medicinal and aromatic plants from Sudan. Nat Prod Bioprospect. 2012;2:92-103.

18. Mahmoud MA, Khidir MO, Khalifa MA, El Ahmadi AMB, Musnad HAR, Mohamed E. Sudan: country report to the FAO international technical conference on plant genetic resources (Leipzig 1996), Khartoum, Sudan. 1996.

19. Abdalla W, Abdallah E. Promising Sudanese medicinal plants with antibacterial activity-a review article. Biol Forum. 2016;2016:299-323.

20. EL-Kamali HH, EL-Amir MY. Antibacterial activity and phytochemical screening of ethanolic extracts obtained from selected Sudanese medicinal plants. Curr R J Biol Sci. 2010;2:143-6.

21. Ibrahim A. Anthelmintic activity of some Sudanese medicinal plants. Phytother Res. 1992:6:155-7.

22. Ali H, König G, Khalid S, Wright A, Kaminsky R. Evaluation of selected Sudanese medicinal plants for their in vitro activity against hemoflagellates, selected bacteria, HIV-1-RT and tyrosine kinase inhibitory, and for cytotoxicity. J Ethnopharmacol. 2002;83:219-28.

23. Saeed ME, Abdelgadir H, Sugimoto Y, Khalid HE, Efferth T. Cytotoxicity of 35 medicinal plants from Sudan towards sensitive and multidrug-resistant cancer cells. J Ethnopharmacol. 2015;174:644-58.

24. Yagi SM, Yagi Al. Traditional medicinal plants used for the treatment of diabetes in the Sudan: a review. Afr J Pharm Pharmacol. 2018;12:27-40.

25. Dirar Al, DHM A, Wada M, Mohamed MA, Watanabe T, Devkota HP. Effects of extraction solvents on total phenolic and flavonoid contents and biological activities of extracts from Sudanese medicinal plants. South Afr J Bot. 2018; in press.

26. Prinsloo G, Nogemane N, Street R. The use of plants containing genotoxic carcinogens as foods and medicine. Food Chem Toxicol. 2018;116:27-39.

27. Shimamura T, Sumikura Y, Yamazaki T, Tada A, Kashiwagi T, Ishikawa H, Matsui T, Sugimoto N, Akiyama H, Ukeda H. Applicability of the DPPH assay for evaluating the antioxidant capacity of food additives-inter-laboratory evaluation study. Anal Sci. 2014;30:717-21.

28. Yang Z, Wang Y, Wang Y, Zhang Y. Bioassay-guided screening and isolation of $a$-glucosidase and tyrosinase inhibitors from leaves of Morus alba. Food Chem. 2012;131:617-25.

29. Bitou N, Ninomiya M, Tsujita T, Okuda H. Screening of lipase inhibitors from marine algae. Lipids. 1999;34:441-5.

30. Sultana B, Anwar F, Ashraf M. Effect of extraction solvent/technique on the antioxidant activity of selected medicinal plant extracts. Molecules. 2009;14: 2167-80.

31. Zieliński H, Kozłowska H. Antioxidant activity and total phenolics in selected cereal grains and their different morphological fractions. J Agric Food Chem. 2000;48:2008-16.

32. Evans JL, Goldfine ID, Maddux BA, Grodsky GM. Oxidative stress and stressactivated signaling pathways: a unifying hypothesis of type 2 diabetes. Endocr Rev. 2002;23:599-622

33. Ning W, Peng X, Ma L, Cui L, Lu X, Wang J, Tian J, Li X, Wang W, Zhang L. Enhanced secondary metabolites production and antioxidant activity in postharvest Lonicera japonica Thunb. In response to UV radiation. Innov Food Sci Emerg Technol. 2012;13:231-43.

34. Hollman PCH. Evidence for health benefits of plant phenols: local or systemic effects? J Sci Food Agric. 2001;81:842-52.
35. Foti M, Piattelli M, Baratta MT, Ruberto G. Flavonoids, coumarins, and cinnamic acids as antioxidants in a micellar system. Structure- activity relationship. J Agric Food Chem. 1996:44:497-501.

36. Sadiq MB, Hanpithakpong W, Tarning J, Anal AK. Screening of phytochemicals and in vitro evaluation of antibacterial and antioxidant activities of leaves, pods and bark extracts of Acacia nilotica (L.) Del. Ind Crop Prod. 2015;77:873-82.

37. Maldini M, Montoro P, Hamed Al, Mahalel UA, Oleszek W, Stochmal A, Piacente S. Strong antioxidant phenolics from Acacia nilotica: profiling by ESI-MS and qualitative-quantitative determination by LC-ESI-MS. J Pharm Biomed Anal. 2011;56:228-39.

38. Abu-Taleb AM, El-Deeb K, Al-Otibi FO. Assessment of antifungal activity of Rumex vesicarius $\mathrm{L}$. and Ziziphus spina-christi (L.) Willd. Extracts against two phytopathogenic fungi. Afr J Microbiol Res. 2011;5:1001-11.

39. Pal RS, Ariharasivakumar G, Girhepunjhe K, Upadhay A. In-vitro antioxidative activity of phenolic and flavonoid compounds extracted from seeds of Abrus precatorius. Int J Pharm Pharm Sci. 2009:1:136-40.

40. Kenwat R, Prasad P, Sahu RK, Roy A, Saraf S. Preliminary phytochemical screening and in vitro antioxidant efficacy of fruit oil of Martynia annua. UK J Pharm Biosci. 2014;2:16-22.

41. Madani I, Sulieman Y, Sinada F, Mohamed HA. Martynia annua L. (Martyniaceae): a new record for the flora of Sudan. Sudan J Sci. 2017:9:11-8.

42. Zheleva-Dimitrova D, Gevrenova R, Zaharieva MM, Najdenski H, Ruseva S, Lozanov V, Balabanova V, Yagi S, Momekov G, Mitev V. HPLC-UV and LC-MS analyses of acylquinic acids in Geigeria alata (DC) Oliv. \& Hiern. And their contribution to antioxidant and antimicrobial capacity. Phytochem Anal. 2017;28:176-84

43. Do QD, Angkawijaya AE, Tran-Nguyen PL, Huynh LH, Soetaredjo FE, Ismadji $\mathrm{S}$, Ju Y-H. Effect of extraction solvent on total phenol content, total flavonoid content, and antioxidant activity of Limnophila aromatica. J Food Drug Anal. 2014;22:296-302.

44. Bischoff $\mathrm{H}$. The mechanism of alpha-glucosidase inhibition in the management of diabetes. Clin Invest Med. 1995;18:303-11.

45. Omara EA, Nada SA, Farrag ARH, Sharaf WM, El-Toumy SA. Therapeutic effect of Acacia nilotica pods extract on streptozotocin induced diabetic nephropathy in rat. Phytomedicine. 2012;19:1059-67.

46. Lunagariya NA, Patel NK, Jagtap SC, Bhutani KK. Inhibitors of pancreatic lipase: state of the art and clinical perspectives. EXCLI J. 2014;13:897.

47. Chipiti T, Ibrahim MA, Singh M, Islam MS. In vitro a-amylase and $a$ glucosidase inhibitory and cytotoxic activities of extracts from Cissus cornifolia planch parts. Pharmacogn Mag. 2017;13:S329.

48. EL-Kamali HH. Ethnopharmacology of medicinal plants used in North Kordofan (Western Sudan). Ethnobotanical Leaflets. 2009;2009:24.

49. Doka I, Yagi S. Ethnobotanical survey of medicinal plants in West Kordofan (Western Sudan). Ethnobotanical Leaflets. 2009;2009:8.

50. Hamm S, Bleton J, Connan J, Tchapla A. A chemical investigation by headspace SPME and GC-MS of volatile and semi-volatile terpenes in various olibanum samples. Phytochemistry. 2005;66:1499-514.

51. Yoshimatsu K, Shimomura K. Plant regeneration on cultured root segments of Cephaelis ipecacuanha A. Richard. Plant Cell Rep. 1994;14:98-101.

52. Thirupathi K, Kumar SS, Raju V, Ravikumar B, Krishna D, Mohan GK. A review of medicinal plants of the genus Cordia: their chemistry and pharmacological uses. J Nat Remedies. 2008;8:1-10.

53. Wickens G. In: Le Houérou HN, editor. Alternative uses of browse species. Browse in Africa: the current state of knowledge. Addis Ababa: ILCA; 1980. p. 155-82.

54. El-Askary HI, Meselhy MR, Galal AM. Sesquiterpenes from Cymbopogon proximus. Molecules. 2003;8:670-7.

55. Singh N, Pandey B, Verma P, Bhalla M, Gilca M. Phyto-pharmacotherapeutics of Cyperus rotundus Linn(Motha): an overview. Indian J Nat Prod Res. 2012;3:467-76.

56. Hafizur RM, Babiker R, Yagi S, Chishti S, Kabir N, Choudhary MI. The antidiabetic effect of Geigeria alata is mediated by enhanced insulin secretion, modulation of $\beta$-cell function, and improvement of antioxidant activity in streptozotocininduced diabetic rats. J Endocrinol. 2012;214:329-35

57. Bhattacharjee R, Khairwal I, Bramel PJ, Reddy K. Establishment of a pearl millet [Pennisetum glaucum (L.) R. Br.] core collection based on geographical distribution and quantitative traits. Euphytica. 2007;155:35-45.

58. El Tahir K, Ageel A, Mekkawi A, Bashir A, Mossa J, Khaled S. Pharmacological actions of the leaves of Solenostemma argel (Hayne): spasmolytic and uterine relaxant activities. Int J Crude Drug Res. 1987;25:57-63.

59. Alamin MA, Yagi Al, Yagi SM. Evaluation of antidiabetic activity of plants used in western Sudan. Asian Pac J Trop Biomed. 2015;5:395-402. 
60. Hamza NAAEN: Physico-chemical properties of fenugreek (Trigonella foneum-graecum) seed proteins. Sudan: PhD Disserataion, University of Khartoum; 2006.

61. Ramalingum N, Mahomoodally MF. Biologic propensities and phytochemical profile of Vangueria madagascariensis JF Gmelin (Rubiaceae): an underutilized native medicinal food plant from Africa. Biomed Res Int. 2014;2014:45-8

62. El Ghazali G, El Tohami M, El Egami AA. Medicinal plants of the Sudan. Part IV. Medicinal plants of northern Kordofan. Khartoum: National Centre for Research vii; 1997.

Ready to submit your research? Choose BMC and benefit from:

- fast, convenient online submission

- thorough peer review by experienced researchers in your field

- rapid publication on acceptance

- support for research data, including large and complex data types

- gold Open Access which fosters wider collaboration and increased citations

- maximum visibility for your research: over $100 \mathrm{M}$ website views per year

At BMC, research is always in progress.

Learn more biomedcentral.com/submissions 